\title{
E-commerce in Russian rural areas as a tool for regional development
}

\author{
Igor Aleksandrov ${ }^{1 *}$, Marina Fedorova ${ }^{2}$, and Alexey Parshukov ${ }^{1}$ \\ ${ }^{1}$ Peter the Great St.Petersburg Polytechnic University, Polytechnicheskaya 29, 195251, St. \\ Petersburg, Russia \\ ${ }^{2}$ Petrozavodsk State University, Lenina 33, 185910, Petrozavodsk, Russia
}

\begin{abstract}
The objective of the paper is to analyze the development of ecommerce in rural areas of North Western Russian District to develop agribusiness and preserve the environment. As far as the researches of development of the e-commerce of the Russian countryside are not ubiquitous, the paper, firstly, relies on the research of the development of e-commerce in Russia, at its whole, where the main market is situated in big cities, and the researches of rural e-commerce abroad. Secondly, the statistical and marketing data helps to enlighten the stage of the development of e-commerce in regions and define the main reasons of its immaturity. With the help of statistical and marketing data we also can suppose the real share of regional e-commerce. As far as its share is not too high for the moment, the list of the most possible goods and products to be produced and sold from rural areas is created along with some recommendations of work with rural population.
\end{abstract}

\section{Introduction}

The two third of the Russian territory makes rural territories. We see the confirmation of low quality of life, low salaries and low conditions of life in the researches of Korolenko A.V. [1]. The goals of sustainable development and preserving of the environment and unique culture make researches think stronger about the possibilities rural areas' revitalizing. Such researches as Patrakova S.S. [2] ascertain rural areas as one of the pillars for the whole territories development.

One of the most important questions for rural people at the present time is the unemployment. The development of e-commerce and selling via Internet agricultural goods and products, hand made products, and non-importables could help locals in search of job of opportunities. For now, according to Lopatkin D.S. and Golikova O. M. [3] e-commerce plays the important role in structural transformation of Russian economy, and we see that with appropriate planning the transformation influence on rural development also.

The objectives of the paper is to revise researches about the possibilities of e-commerce and its influence on the economy of rural territory. According to the research of A.A., Shabunova [4] rural people are more active than citizens and are in search of being useful for the territory, at the same time the authorities credit level is still low, the locals of rural

\footnotetext{
* Corresponding author: a7830298@gmail.com
} 
areas are still rely on themselves. As far as our main hypothesis is that the most feasible development strategy for rural areas is bottom-up development, another important question is to revise whether the population of chosen Russian regions is equipped by necessary physical appliances to be involved in domestic and international e-commerce. And the third question is whether the domestic market demand is appropriate that locals of rural territories are able to satisfy it producing their goods, products and non-importable.

\section{Literature Review}

Unfortunately, the literature on the development of e-commerce in Russian countryside is not so rich. It can be explained, firstly, by the fact that the e-commerce in Russia is at its commencement, so the main interest of the researches is devoted to the development of the e-commerce at its whole. On the other hand, the main players of e-commerce market are situated in big cities like Moscow and Saint-Petersburg, but not the countryside.

According to Petrichenko O. V. and Timofeenko M. A. [5] the market of the Russian ecommerce has its potential to growth and the tendenciaes are positive. We can feature the assertation of Revinova S.Yu. [6] whatever the market of e-commerce is growing but its growth rates have fallen and are not so high at the present time. One of the reason, we see, is the saturation of market and the lack of diversity on the market what can play a positive role in the development of rural e-commerce.

It should be mentioned that the range of researches of the e-commerce phenomenon in the North-Western Federal District is much more less in comparison to Russia. We can find the observation of opportunities and obstacles for the e-commerce development in the research of Litsenberg I.I. [7] devoted to Trans-Baikal Territory where the author revise two possible direction for the development of e-commerce at the Trans-Baikal Territory. Alekperov I. D. [8] revised the opportunities of business consulting for Russian regions to develop e-commerce. Gavruishin O. Yu. et al. (9) show how the structure Russian e-market changes with the appearance of new big regional players. Zinovieva T. M. [10] also points Russian regions as the potential territory for spreading the e-commerce phenomenon as far as the market of big cities is going to saturated. One of the main problems preventing the development e-commerce in Russia Kovalchuk A.V. et al. [11] see low development of logistics and post services.

Anyway, we can find more researches of e-commerce influence on the rural development among foreign authors. According to F. Papandrea and M. Wade [12] a wide range of different kinds and sizes of rural business exist in with the help of Internet commerce in Australia. Only one rural business in this research considered its web-site as useless. The researches of rural e-commerce cases made by D. M. Markley et al. [13] show that for some business having a web-site is to promote its product or good and the enterprise itself. Small farmers and artisans are very interested in e-commerce to sell and promote their goods and products. For sure the development electronic payment simplified and accelerated the development of rural e-commerce. The researches also mention the difficulties with the planning and configurating the web-sites to make them bring profit, because some small entrepreneurs face problems with it. According to the research of Zapata S. D. et al. [14] among $70 \%$ farmers of the USA had access to the Internet and 43 $\%$ of them used it for their business. As Zapata S. D. et al. [15] ascertain the registration on a special platform helps to increase direct sells on $0.7 \%$, to find new marketing contacts on $2.6 \%$ and new customers on $1.5 \%$ minimum.

D. Reuschke, C. Mason [16] assure that the development of broadband Internet will not strive the development of home-based business connected with digital engagement. Moreover, the researchers note that at the present time the share of the home-based business to sell with the help of the Internet is very small, but their proportion is bigger than the off- 
line sellers so the transformation of the market is in process. L. Philipa, F. Williams [17] assert that Internet connectivity does not promises rural community to use it for sale and entrepreneurial goals and one of the reasons is supposed to be the reluctance to raise digital literacy. This reason does not aligns with the findings of I. Aleksandrov and M. Fedorova $[18,19]$ demonstrating strong will to familiarize with the tools of earning extra money or getting major income with the help of Internet. But we can explain it by differences of the qualities of life in the UK represented in the research of L. Philipa, F. Williams [17] and in Russian villages, represented in the researches of I. Aleksandrov and M. Fedorova $[18,19]$.

\section{Methodology}

As far as our research goal is the regional development as the peril of the sustainable development of the whole country of the Russian Federation, the regions of the NorthWestern Federal District were chosen. This region is relatively remote from the capital of Russia, Moscow, and is situated closer to the second biggest city of the country, SaintPetersburg. At the same time Saint-Petersburg is the main city of the North Western Federal District. The following regions were chosen for the paper, Arkchangelskaya Oblast, Republic of Karelia, Republic of Komi, Vologodskaya Oblast, Kaliningradskaya Oblast, Leningradskaya Oblast, Murmanskaya Oblast, Novgorodskaya Oblast, Pskovskaya Oblast. Nenetskiy Avtonmniy Okrug was excluded of the research due to its great difference in sight of its GPG which is provided by oil production.

The main data sources for the research were the reports the East-West Digital News to analyze the demand on the products among Russian consumers and understand the geography of the demand. Another source is the report with the data made by Yandex [20] to estimate which regions of Russia are involved in e-commerce at the present time and which regions are at the backstage. Moreover, the statistics data about the share of computer use and the share of the Internet use from the Russian Federal Service of Statistics [21] were gathered. Moreover, the data about Russian demand and the share of the Russian e-commerce in rural areas were gathered with the help of the reports of DataInsight, Research of RAEC, DataInsight \& PayPal report, and the report the "Economy of Runet”.

The second stage of the research was to gather and to analyse the statistics of personal computer users and the statistics of users of the Internet with the help of personal computers. As far as the Federal Statistics Service possesses the data for the period from 2014 to 2019, it corresponds with the chosen period of the research. Nevertheless, smartphones and tablets are replacing the personal computer audience, we assume that for the entrepreneurial activity a personal computer connected to the Internet is essential. That is why the share of the users of personal computers and share of users connected to the Internet via personal computer were revised to understand the potential of e-commerce development in abovementioned regions.

The last stage was to make recommendations and forecast the possible line of ecommerce development in rural areas according to the analyzed literature, statistics, reports and researches elaborated by the authors earlier.

\section{Research}


According to the report of the East-West Digital News [22] at the present time the target audience for e-commerce enterprises is not only Moscow and Saint-Petersburg, the greatest cities of Russia, but most of all, cities with the population from 300 thousand to 1 million people. As a rule, such cities are the capitals of Russian regions and they are closer to villages in need to be developed. Anyway, according to updated report of the East-West Digital News [23] the Russian market of e-consumers is still modest. According to the report "the number of e-shoppers grew at least $20 \%$ annually" and the highest demand in 2018 in Russia is for clothing ( $23 \%$ ), foot wear ( $33 \%$ ), electronic goods ( $31 \%$ ), home appliances ( $28.3 \%$ ).

According to the research of Yandex [20] Russian Association of Electronic Communications [24] the main channel of sales and promotion of goods and products for small entrepreneurs is social nets, which makes $45 \%$ of sales revenue "for those who process less than 10 orders per day". According to the report of Data Insight and PayPal [25] we see that $14 \%$ of the population of Russian regions sold used goods or goods which did not fit, $6 \%$ sold other products, including hand-made products, $13 \%$ of the population sold or proposed different services. The results of the report also ascertain that nevertheless the share of peripheral e-sellers is small but the individuals are involved in e-business are the same way active and serious as the entrepreneurs of big cities. That is why we also can suppose and agree with the researchers of Data Insight and PayPal [25] that the process of the development of e-commerce at less-favored territories takes more time but it is in process.

We can compare the share of B2C (business to consumers ) sellers from the North Western Federal District and other regions from Russia with the help of the Table 1. As we see the share of the North Western Federal District makes only $3.2 \%$ and one of the smallest in Russia. Speaking about non-importables, possible to be produced and sold in rural areas the last report of the Russian Association of Electronic Communications [26] also mentions the stable rising trend of streamers and bloggers.

Table 1. The share of Russian regions of B2C sells (source: elaborated by the authors according to the data of Yandex Checkout (20)).

\begin{tabular}{|l|l|l|}
\hline$№$ & Region of Russian & $\%$ \\
\hline 1 & Moscow and region & 33.6 \\
\hline 2 & Ural Federal District & 11.1 \\
\hline 3 & Volga Federal District & 10.1 \\
\hline 4 & Saint-Petersburg and region & 8.3 \\
\hline 5 & Siberian Federal District & 6.5 \\
\hline 5 & Southern Federal District & 6.5 \\
\hline 7 & Other region of Central Federal District & 6.0 \\
\hline 8 & Other & 5.1 \\
\hline 9 & Far Eastern Federal District & 3.7 \\
\hline 10 & North-Western Federal Region & 3.2 \\
\hline 10 & No registration & 3.2 \\
\hline 11 & North Caucasian Federal District & 2.8 \\
\hline
\end{tabular}

As to the users of personal computers from regions chosen for the paper, we can see (Figure 1) that its share differs from one region to another in the North Western Federal District. The highest share is always in Murmanskaya Oblast. The second place takes the Kaliningradskaya Oblast, and then the Republic of Komi. The Arkchangelskaya Oblast, the Leningradskaya Oblast which neighbors with Saint-Petersburg, the Republic of Karelia are in the middle. And the regions with the lowest share of personal computers' users are Pskovskaya Oblast and Vologodskaya Oblast. 


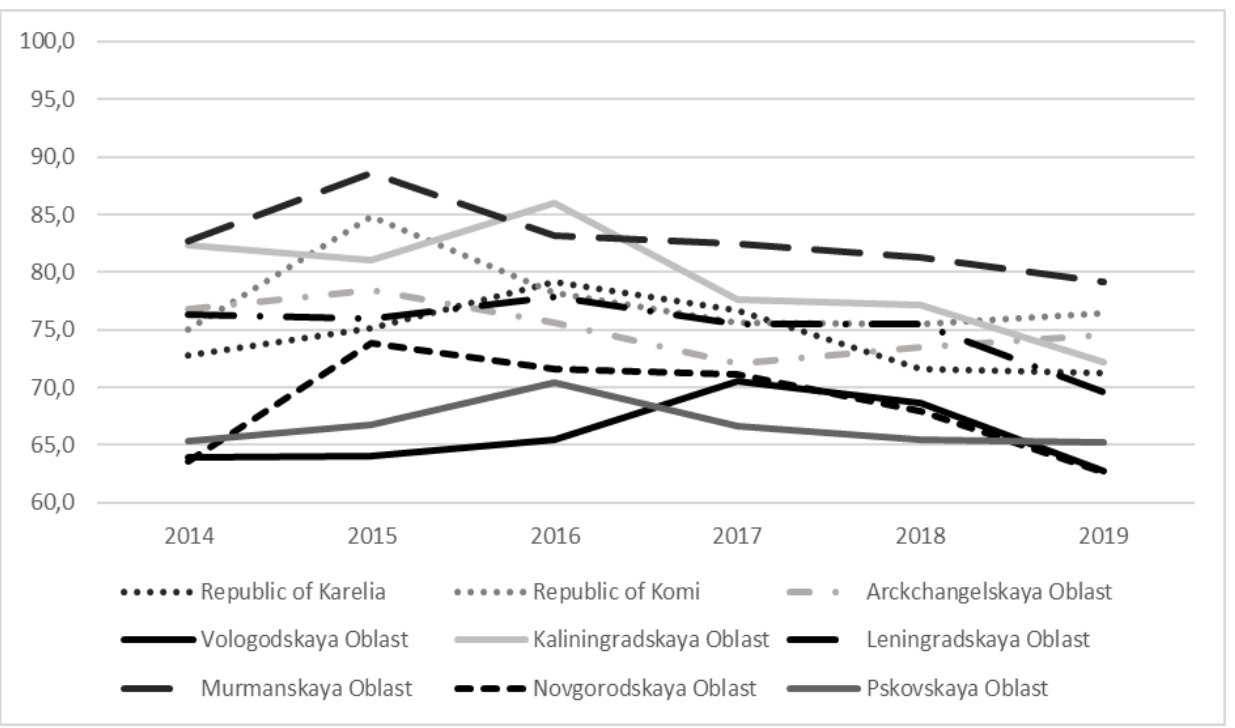

Fig. 1. The share of users of personal computers in the North Western Federal District, 2014 - 2019 years, $\%$ (source: elaborated by the authors).

We also can see that the highest share of Internet users from personal computers is Murmanskaya Oblast, Kalinigradskaya Oblast and the Republic of Komi, the lowest share is in Pskovskaya Oblast and Vologodskaya Oblast, and Arkchangelskaya Oblast, Leningradskaya Oblast, the Republic of Karelia and Novgorodskaya Oblast are in the middle (Figure 2).

The research of the attitudes to the Internet use among the population of the North Western Federal District (Table 2) show that the most popular answer to refuse to be connected to the Internet is the lack of wish, lack or total absence of interest to the Internet use. The highest share of the population not interested in the Internet use is registered in Novgorodskaya Oblast and it makes $27 \%$. It does not correlate with the share of personal computer users among the region of the North Western Federal District, because the lowest share of the personal computer users is in Vologodskaya Oblast with the same lowest share of Internet connected users. But the share of users of the Vologodskaya Oblast take only the second place among the highest share of those who are not interested to be connected to the Internet. The highest expenses to be connected to the Internet are in Vologodskaya Oblast what can partly explain the lack of interest and lack of motivation to be connected to the Internet. The share of the responses when the lack of skills and technical equipment were noted as the reasons to be connected to the Internet in Novgorodskaya Oblast also. So we can see that Novgorodskaya Oblast and Vologodskaya Oblast possess the lowest Internet connection, literacy and motivation to be involved in the processes of the world wide web. 


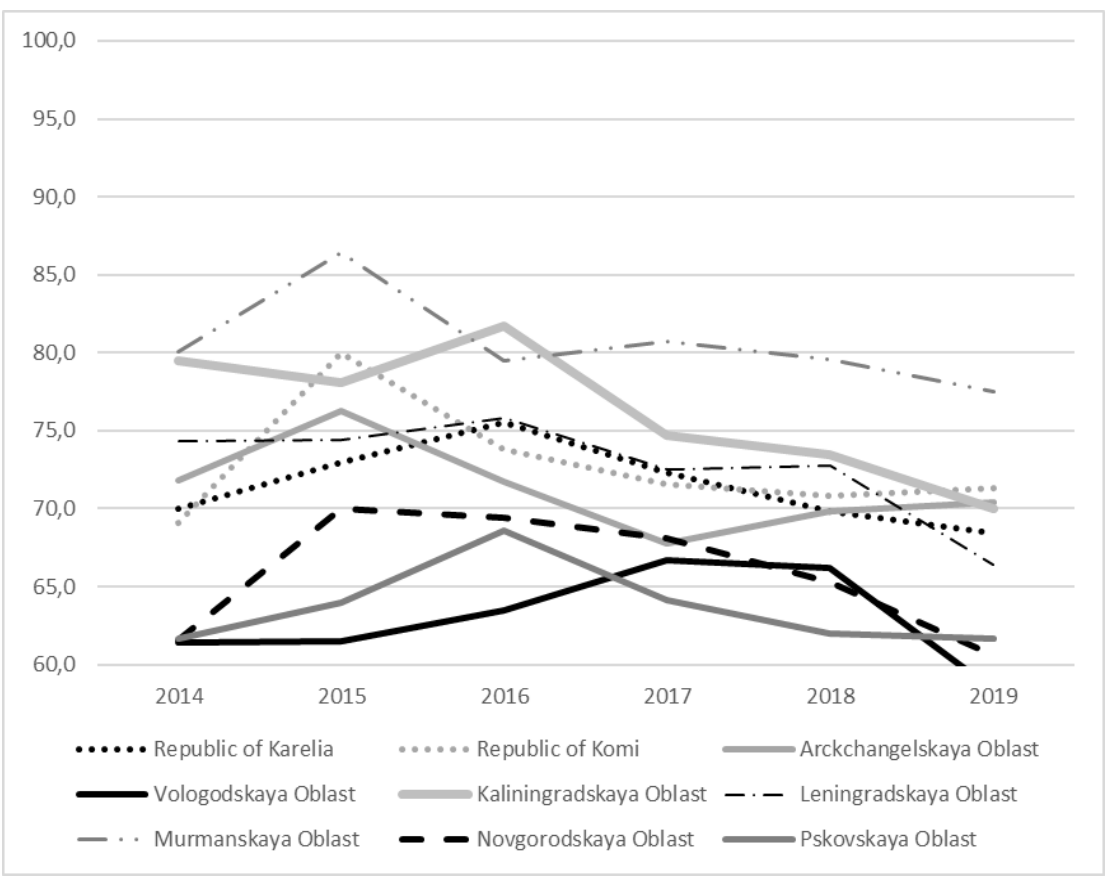

Fig. 2. The share of users of personal computers in the North Western Federal District connected to the Internet, 2014 - 2019 years, \% (source: elaborated by the authors).

Table 2. The share of households refused to Internet connected due to different reasons

\begin{tabular}{|c|c|c|c|c|c|c|c|}
\hline 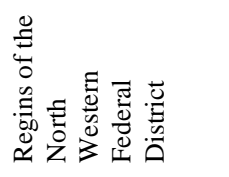 & 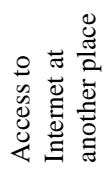 & 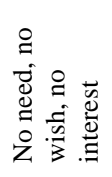 & 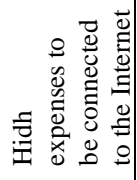 & 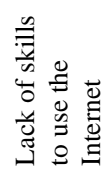 & 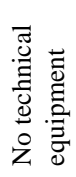 & 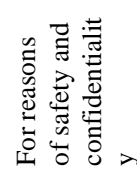 & 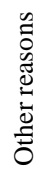 \\
\hline Republic of Karelia & 0,2 & 16,9 & 1,9 & 5,4 & 2,7 & 0,1 & 1,8 \\
\hline Republic of Komi & 0,5 & 17,4 & 3,9 & 9,5 & 1,0 & 0,0 & 2,0 \\
\hline $\begin{array}{l}\text { Arckchangelskaya } \\
\text { oblast }\end{array}$ & 0,9 & 17,4 & 1,8 & 4,4 & 1,8 & 0,1 & 3,8 \\
\hline $\begin{array}{l}\text { Vologodskaya } \\
\text { oblast }\end{array}$ & 1,1 & 22,7 & 7,5 & 10,3 & 3,0 & 0,0 & 2,2 \\
\hline $\begin{array}{l}\text { Kaliningradskaya } \\
\text { oblast }\end{array}$ & 1,2 & 15,5 & 2,9 & 3,3 & 1,4 & 0,0 & 3,0 \\
\hline $\begin{array}{l}\text { Leningradskaya } \\
\text { oblast }\end{array}$ & 1,7 & 18,4 & 3,7 & 9,8 & 0,9 & 0,4 & 3,4 \\
\hline $\begin{array}{l}\text { Murmanskaya } \\
\text { oblast }\end{array}$ & 0,3 & 14,0 & 3,6 & 7,1 & 0,0 & 0,3 & 0,8 \\
\hline $\begin{array}{l}\begin{array}{l}\text { Novgrodskaya } \\
\text { oblast }\end{array} \\
\end{array}$ & 1,3 & 27,0 & 6,8 & 10,9 & 4,9 & 0,4 & 2,8 \\
\hline Pskovskaya oblast & 1,9 & 22,0 & 4,9 & 7,1 & 3,2 & 0,0 & 1,4 \\
\hline
\end{tabular}

As to the $\mathrm{C} 2 \mathrm{C}$ sales inside Russian regions, according to the research of Data Insight (27) the segment the $\mathrm{C} 2 \mathrm{C}$ sales in Russia makes their main source for life in Russia. But they need to broaden their sales, because at the present time $92 \%$ of their sales are inside of their town or village what is inappropriate for small towns and unfavored villages. Only 2 $\%$ of Russian rural people perform $\mathrm{C} 2 \mathrm{C}$ sells, as to little towns, their share makes only $3 \%$ in 2018. But it should be mentioned that the share of the North-Western Federal District $\mathrm{C} 2 \mathrm{C}$ sales is the highest in Russia and makes $16 \%$. 


\section{Discussion}

We see that the majority of Russian population in the region of the North Western Federal District has personal computers and is connected to the Internet (Fig. 1, Fig. 2). As far as our previous researches of rural people attitudes to earn extra money or to have major income with the help of Internet [18,19], we can ascertain that for now the population is equipped by main appliances to run their own with the help of Internet. On the other hand, we also see lack if interest and motivation as a reason not to be connected to the Internet (Table 2), what also partly aligns with the finding of our previous researches $[18,19]$. That is why we suppose that rural people need more information about possibilities of selling goods and products via Internet, producing non-importables and selling them also via Internet.

Firstly, the information should include the list of goods and products on demand from Russian market. According to the research of the East-West Digital News [23] of Russian demand on products sold in the Internet we collected the table of potential products to be produced and sold by entrepreneurs from remote and less favored areas of Russia (Table 3).

Table 3. Products and goods to be produced by entrepreneurs from remote and less favored areas of Russia (source: elaborated by authors with the data of East-West Digital News Report).

\begin{tabular}{|l|c|}
\hline Product Category & Demand, \% \\
\hline Clothing and shoes (incl. sporting, excluding. children's) & 36 \\
\hline Personal care products & 34 \\
\hline Cosmetics and perfumes & 33 \\
\hline Toys, games and hobby items & 28 \\
\hline Pharmaceutical and dietary supplements & 24 \\
\hline DIY, cleaning supplies, tableware & 23 \\
\hline Children's clothing and shoes & 22 \\
\hline Home and interior textiles & 19 \\
\hline Bags, belts and accessories & 18 \\
\hline
\end{tabular}

Secondly, the population should be taught to promote and sell goods, products and nonimportables with the help of Internet. The information should include such points as creating a web-page and pages in social net, choosing the most appropriate channel to sell goods and products, choosing possibilities to promote goods and products, delivery and payment possibilities, etc. Such education can boost rural population entrepreneurial activity, what is positive for the municipal economy and, as a result, for the regional economy, if we regard the municipality as a structural unite of the whole regional economy.

\section{Conclusion}

The research was devoted to analyze the development of e-commerce in the regions of the North Western District of the Russian Federation. The lack of Russian researches on the theme of rural e-commerce development was partly replaced by the review of the researches on the development of e-commerce in Russia, and the development of rural ecommerce abroad. As we see, the majority of the population of Russian regions of the North-Western Federal Region has personal computers with the access to the Internet. We also can assume that the share of individual entrepreneurs from Russian regions make 14 $\%$. This share is not high enough and should be developed to make less favored territories more sustainable. The review of the literature on the question of the development of Russian e-commerce also confirms that this phenomenon is only at its commencement. At the same time there are some regions where the population share from 20 to $27 \%$ refuses to be connected to the Internet due the lack of interest. That fact, as also the data about the 
lack of computer and Internet literacy, confirms that the population is in need to be taught to earn money with the help of the Internet. The strong need of new ways of earning money is explained by the level of salary and the quality of life in those regions, which is less than in the capital of Russia and in big cities. The problem of unemployment worsens the problem and reinforces the outmigration to big cities. But we ascertain that people can sell products and goods via Internet and run their own business in more comfortable rural circumstances and better environment. As our previous research show, rural population is interested in such activity but is not aware of technologies and possibilities. According to the literature review we also see good examples of e-commerce in rural areas which became the source of main income for people. For now, the questions for rural e-business are which niche to choose, how to sell, via social channels or with the help of a web-site only. Mainly, it depends on the size of an enterprise, and for small entrepreneurs the social nets are more appropriate due to their easiness in use and not expensive and free expenses to be involved in e-commerce. That is why the list of goods and products on demand on the Russian e-market was created with the help of the data provided by East-West News Report.

\section{References}

1. A.V., Korolenko, Territorial Development Issues, 2(32), (2018)

2. S.S., Patrakova, Territorial Development Issues, 8, 1-16 (2020) DOI: 10.15838/tdi.2020.1.51.1

3. D.S. Lopatkin, O.M. Golikova, ASR: Economics and Management, 5, 259-261 174 (2016)

4. A.A., Shabunova, Problems of Territory's Development, 83(3), 7-17 (2016)

5. O.V. Petrichenko, M.A. Timofeenko, Sinnergia Nauk, 19, 48-53 (2018)

6. S.Yu., Revinova, RUDN Journal of Economics, 25(4), 487-97 (2017)

7. I. I. Litsenberg, Moscow journal, 8, 250-63 (2019) DOI: 10.24411/2413-046X-201918062

8. I. D. Alekperov, Intellectual Resources For Regional Development, 2 6-9 (2016)

9. O.Yu. Gavryushin, S.I. Dolgov, Yu. A. Savinov., E.V. Taranovskaya, Russian Foreign Economic Journal, 8, 78-93 (2019)

10. M. T. Zinovieva, Vestnik of the Plekhanov Russian University of Economics, 24(4), 7481 (2018)

11. A.V. Kovalchuk, N.A. Cherkas, N. Yu., Saibel, Aktualniye voprosi sovremennoi economiki, 173-8 4,(2019)

12. F. Papandrea, M. Wade, E-commerce in Rural Areas - Case studies Rural Industries Research and Development Corporation, 00/185 (2000) [On-line] https://www.agrifutures.com.au/wp-content/uploads/publications/00-185.pdf

13. D. M. Markley, D. L. Barkley, R. D. Lamie, Case Studies of E-Commerce Activity In Rural And Small Town Businesses: Clemson University, 2007. [On-Line] https://ageconsearch.umn.edu/bitstream/112894/2/E-Commerce\%20Project.pdf

14. S.D. Zapata, O. Isengildina, C. Carpio, D. Lamie, Journal of Food Distribution Research, 47(2), 1-18 (2016)

15. S.D. Zapata, O. Isengildina, C. Carpio, D. Lamie, Journal of Agribusiness, 29(1), 15980 (2011)

16. D. Reuschke, C. Mason, Futures 102542 DOI: 10.1016/j.futures.2020.102542 
17. L. Philipa, F. Williams, Journal of Rural Studies, 68, 306-18 (2019) DOI: 10.1016/j.jurstud.2018.09.011

18. I. Aleksandrov, M. Fedorova, E3S Web of Conferences, 164, 07008 (2020) DOI: $10.1051 / \mathrm{e} 3$ sconf $/ 202016407008$

19. I. Aleksandrov, M. Fedorova, E3S Web of Conference, 110, 02019,(2019) DOI 10.1051/e3sconf/201911002019

20. Checkout, Yandex. Social commerce in Russia: social networks, messengers, classifies ad platforms and sharing economy as sales channels. 2018. [On-Line] https://money.yandex.ru/i/forms/2018_social_en.pdf

21. Federal Service of Statistics of the Russian Federation. [Online] https://www.gks.ru/free_doc/new_site/business/it/fed_nabl-croc/index.html.

22. News, East-West Digital. Internet commerce in Russia. 2015. [On-line] https://www.rvc.ru/upload/iblock/0ee/e-commerce_resume_vk_part1_v1.pdf

23. E-Coomerce In Russia Part 1: Market Trends \& Plaayers' Strategies . 2019. [On-line] http://ewdn.com/files/russian_ecom_part1.pdf

24. Communication, Russian Association of Electronic. Economy of Runet 2015 - 2016. 2016. [On-line] http://old.raec.ru/upload/files/EconomicaRunetaItogy2016.pdf

25. DataInsight, PayPal -. On-line Economy of Russia: How Residents of Big cities, Medium And Small Towns Buy, Sell And Pay In The Internet. 2018. [On-line] http://datainsight.ru/sites/default/files/PayPalDataInsight\%20study_2018.pdf

26. Communications, Russian Assoviation of Electronic. Research of RAEC: Runet Economy During COVID-19 - Rise And Transform . Russian Assoviation of Electronic Communications . [On-line] 2020. https://raec.ru/live/raec-news/11580/.

27. Insight, Data. Internet commerce in Russia 2018. Figure and facts. 2018. [On-line] http://datainsight.ru/sites/default/files/DI-RIF2018.pdf 